\title{
Impacts of mercury contaminated mining waste on soil quality, crops, bivalves, and fish in the Naboc River area, Mindanao, Philippines.
}

\author{
J D Appleton ${ }^{\mathrm{a}, *^{*}}$, Weeks J M ${ }^{\mathrm{b}}$, Calvez J P S ${ }^{\mathrm{c}}$ and Beinhoff, $\mathrm{C}^{\mathrm{d}}$ \\ ${ }^{a}$ British Geological Survey, Keyworth, Nottingham, England \\ ${ }^{\mathrm{b}}$ Centre for Environment, Fisheries \& Aquaculture Sciences (CEFAS), Pakefield Road, Lowestoft, Suffolk, \\ England \\ ${ }^{\mathrm{c}}$ Mines and Geosciences Bureau, Quezon City, Philippines \\ ${ }^{d}$ United Nations Development Organisation (UNIDO), Vienna, Austria
}

\begin{abstract}
Rice paddy fields in the Naboc area, near Monkayo on the island of Mindanao, Philippines, have been irrigated four times a year over the last decade using Naboc River water contaminated with mercury (Hg) by artisanal gold mining in the Diwalwal area. Silt containing up to at least $90 \mathrm{mg}$ Hg/kg (d.w.) has been deposited in rice paddy fields during the 1990's and this has been repeatedly mixed into the rice root zone through ploughing. Hg in the rice paddy field soils averages $24 \mathrm{mg}$ $\mathrm{Hg} / \mathrm{kg}$ and generally exceeds the UK and Canadian soil quality thresholds for agricultural soils as well as the proposed Dutch Intervention value and the USEPA soil ingestion Soil Screening Level (SSL) for inorganic Hg. Much lower Hg concentrations (0.05-0.99 mg/kg) within the range expected for uncontaminated soils, characterise soils on which corn and bananas are cultivated, largely because these are not irrigated with Hg-contaminated water from the Naboc River. The estimated total weekly MeHg intake for a person living in the Naboc area related to the weekly consumption of $2.1 \mathrm{~kg}$ of rice grown on Hg contaminated soils (15 $\mu \mathrm{g} \mathrm{MeHg})$ in conjunction with 1
\end{abstract}

\footnotetext{
* Corresponding author. British Geological Survey, Nicker Hill, Keyworth, Nottingham NG12 5GG, England. Tel.: +44-115-936-3207; Fax: +44-115-936-3200.

E-mail address: jda@bgs.ac.uk (J.D. Appleton)
} 
$\mathrm{kg}$ of fish (220 $\mu \mathrm{g} \mathrm{MeHg})$ and 100g of mussels (50 $\mu \mathrm{g}$ MeHg) from the Naboc River, would total $285 \mu \mathrm{g} \mathrm{MeHg}$ (equivalent to $4.75 \mu \mathrm{g} / \mathrm{kg}$ bw for a $60 \mathrm{~kg}$ adult), which is nearly three times the JECFA PTWI of $1.6 \mu \mathrm{g} / \mathrm{kg}$ bw. This will significantly contribute to the population mercury exposure and might explain why 38\% of the local inhabitants were classified as Hg intoxicated during a mercury toxicity assessment (Drasch et al., 2001).

Keywords: , water quality, sediment quality, rice, mussels, cadmium, lead, human exposure.

\section{Introduction}

The gold mining centre of Diwalwal (also know as Mt. Diwata), located within the mountainous east Mindanao Ridge, is one of the largest artisanal gold mining centres on the island of Mindanao (Appleton et al., 1999). The focus of mining activity at Diwalwal lies in the headwaters of a series of minor tributaries of the Naboc River, which subsequently joins the north-flowing Agusan River (Figure 1). Environmental monitoring surveys in the 1990's revealed extensive mercury pollution of water and sediment in the Naboc River (Appleton et al., 1999). .

Massive, uncontrolled small-scale mining and mineral processing in the headwaters of the Naboc River in the late 1980's and early 1990's, involving up to 100,000 people resulted in severe pollution of the irrigated rice paddy fields in the Lower and Upper Naboc Communal Irrigation Systems, located either side of the Naboc River and serving 600 farmers and their families (Figure 1). Rice yields declined from $6,000 \mathrm{~kg} / \mathrm{ha}$ in the 1980 's to $3,000 \mathrm{~kg} / \mathrm{ha}$ in the 1990 's caused by the high load of fine suspended silt in the irrigation water. The death of a significant number of water buffalo was tentatively diagnosed as cyanide poisoning and farmers working in the affected paddy fields had reported unexplained skin diseases (Appleton, 2000). In response to these reported problems, the United Nations Industrial Development Organisation (UNIDO) funded studies of (1) the extent and magnitude of mercury pollution in the Naboc River and neighbouring agricultural areas (Appleton, 2000); (2) the potential risk to human health from consumption of rice cultivated in rice paddy fields irrigated by mercury-contaminated mine waste water (Weeks, 2000); and (3) an 
evaluation of the influence of mercury on the health of people living in the Diwalwal mining centre and the villages of Naboc, Tubo-Tubo, Babag and Mamonga (Figure 1; Böse-O’Reilly et al., 2000, Drasch et al., 2001). The objective of this paper is to provide a link between earlier regional studies (Appleton et al., 1999) and the detailed health studies (Drasch et al., 2001), which showed that 38\% of the local inhabitants were classified as Hg intoxicated. Because consumption of contaminated rice and fish is the primary route of potential exposure to heavy metals, this paper concentrates on mercury in soil, crops, and aquatic biota and assesses the potential hazard to the local people caused by $\mathrm{Hg}, \mathrm{Cd}$, and $\mathrm{Pb}$ in locally produced food sources. Greater detail on water and sediment quality monitoring is reported by Appleton (2000). 


\section{Sampling and analytical methods}

\subsection{Sediment, soil and water}

Bottom sediment (BS) samples (Figure 1) were collected by wet screening of river or stream-bed sediment through a $150 \mu \mathrm{m}$ sieve, using a minimal amount of water to avoid the loss of fine silt and clay fractions. Suspended particulate matter (SPM) samples were obtained by filtering $500 \mathrm{ml}$ water through $47 \mathrm{~mm}$ diameter, $0.45 \mu \mathrm{m}$ Cellulose Nitrate Membrane Filters (Whatman ${ }^{\mathrm{TM}}$ ) using $250 \mathrm{ml}$ and $500 \mathrm{ml}$ capacity $\underline{\text { Nalgene }} \mathrm{T}^{\mathrm{TM}}$ filter holders and receivers and a hand operated vacuum pump. Filter membranes were carefully removed to avoid contamination and stored in $30 \mathrm{ml}$ $\underline{\text { Sterilin }^{\mathrm{TM}}}$ tubes.

Soil sampling was carried out in the agricultural terrains adjacent to the Naboc River, comprising (i) the rice paddy fields of the Lower and Upper Naboc Communal Irrigation Systems; (ii) corn fields on non-irrigated land between the paddy fields and (iii) banana plantations adjacent to the Agusan River (Figure 1). Composite soil samples were collected from sites about 10-20 m apart at and immediately below the root depth of the rice, corn, and banana plants. Sediment and soil samples were sealed in plastic securitainers to avoid evaporative losses and oxidation.

Stream and well water $\mathrm{pH}$, temperature, Eh, and conductivity were determined in the field using a series of temperature-compensated electrodes and meters. Water samples for chemical analysis were filtered through $50 \mathrm{~mm}$ diameter $\underline{\text { Sartorius Sartolab PTM }} 0.45 \mu \mathrm{m}$ disposable SFCA membranes using $50 \mathrm{ml}$ disposable syringes and collected into $250 \mathrm{ml} \underline{\text { Nalgene }}{ }^{\mathrm{TM}}$ LPDE bottles. Some water samples for analysis at the BGS were collected using $25 \mathrm{~mm}$ diameter, $0.45 \mu \mathrm{m}$ Millipore $^{\mathrm{TM}}$ cellulose acetate membranes into $30 \mathrm{ml}$ Nalgene ${ }^{\mathrm{TM}}$ HPDE bottles. At each site, the suite of water samples collected included: (1) $250 \mathrm{ml}$ filtered water preserved with $1 \% \mathrm{v} / \mathrm{v} \mathrm{HNO}_{3}$ (Merck) for determination of $\mathrm{Hg}, \mathrm{Cu}, \mathrm{Cd}, \mathrm{Cr}, \mathrm{Pb}, \mathrm{Zn}, \mathrm{Cd}$; and (2) $250 \mathrm{ml}$ unfiltered water with pH adjusted to 12 with solid $\mathrm{NaOH}$ for $\mathrm{CN}$ analysis. A number of $30 \mathrm{ml}$ samples, filtered and preserved with $0.3 \mathrm{ml}$ conc. $\mathrm{HNO}_{3}+0.3 \mathrm{ml} 0.2 \mathrm{vol} . \% \mathrm{~K}_{2} \mathrm{CrO}_{7}$ were collected for total $\mathrm{Hg}$ analysis at the BGS by a UK Accrediatation Services cold vapour atomic fluorescence spectroscopic (CVAFS) method to a practical detection limit of $30 \mathrm{ng} / \mathrm{L}$ using a PS-Analytical AFS. Quality control 
was achieved by analysis of duplicates, blanks, aqueous quality control standards and AQUACHECK proficiency testing samples. Results for duplicate samples analysed in the BGS and the Philippines Mines and Geosciences Bureau (MGB) laboratories agreed well (Figure 2). Bottom sediment (BS), suspended sediment (SS) and soil samples were dried at $<40^{\circ} \mathrm{C}$. SS samples were digested with the cellulose filter membrane in aqua regia at $<50^{\circ} \mathrm{C}$. Dried BS and soil samples were disaggregated, hand ground in a porcelain mortar and pestle and 1.0g digested overnight in $50 \%$ aqua regia at room temperature then gently refluxed for 2 hours at about $106^{\circ} \mathrm{C}$, cooled and made up to $20 \mathrm{ml}$. For the determination of $\mathrm{Hg}$, organically bound mercury was released by oxidation with $6 \%$ potassium permanganate solution. Mercury in water, sediment and soil at the MGB was determined by flameless atomic absorption spectrophotometer (Hiranuma HG-1) to a detection limit of $0.1 \mu \mathrm{g} / \mathrm{L}$ in water and $0.04 \mathrm{mg} / \mathrm{kg}$ in sediment and soil using $\mathrm{SnCl}_{2}$ as a reduction agent (Appleton, 2000). CN in filtered waters was determined by ion selective electrode (ISE) using a Jenway 3340 Ion Meter. $\mathrm{Cu}, \mathrm{Cd}, \mathrm{Cr}, \mathrm{Pb}, \mathrm{Zn}, \mathrm{Cd}$ in filtered waters and aqua regia soluble $\mathrm{Cu}, \mathrm{Cd}, \mathrm{Cr}, \mathrm{Pb}$, and $\mathrm{Zn}$ in sediments and soils were determined by AAS using a Shimadzu AA6800. Quality control of the MGB analysis was achieved by analysis of duplicates, blanks, aqueous and solid quality control standards (GXR-2), and by comparing MGB results with results for samples analysed in the BGS laboratories (Figure 2). Mercury analyses of BS and soil samples at the BGS were carried out on $1 \mathrm{~g}$ milled sub-amples, digested overnight in $50 \%$ aqua regia at room temperature then gently refluxed for 2 hours at about $140^{\circ} \mathrm{C}$, cooled and made up to $50 \mathrm{ml}$. Mercury was then determined by CV-AFS to a practical detection limit for solid samples of 0.02 $\mathrm{mg} / \mathrm{kg}$ using a PS-Analytical AFS. $\mathrm{Cu}, \mathrm{Cd}, \mathrm{Cr}, \mathrm{Pb}$, and $\mathrm{Zn}$ in a $5 \mathrm{ml}$ aliquot of the aqua regia digestate were determined by ICP-AES using a Varian/Vista AX CCD simultaneous instrument with dedicated Varian SPS-5 Autosampler. Instrument calibration was achieved using mixed element standards covering a range of concentrations and the instrument was re-calibrated after not more than 40 samples. Two quality control standards, high and low, were analysed after each calibration, during the run, after no more than ten unknown solutions and at the end of each run to check for drift. Blanks, calibration standards and quality control standards were matrix matched to the samples to be analysed. All reported measurements are based on the average of three replicate 
analyses. National Research Council of Canada marine sediments BEST-1 and PACS-1 were used for quality control. There was good agreement between the MGB and BGS results (Figure 2)

\subsection{Rice}

Samples of rice (Oryza sativa L.) grain from a representative selection of sites within the Naboc, Babag, Mamonga, Tubo-Tubo area (Figure 1) were collected either (1) from the mature rice plants in situ, or (2) in the majority of cases, where rice had previously been harvested, samples were collected from concrete drying beds. In the latter case, each sample comprised a composite of at least 6 sub-samples of the rice being dried. Approximately 300g were taken for each location in a randomised fashion. Samples were placed in plastic bags and kept in a fridge $\left(5^{\circ} \mathrm{C}\right)$ before being dried and subsequently analysed. Grains were thoroughly washed once only and dried at a low temperature $\left(<40^{\circ} \mathrm{C}\right)$ in an oven until a constant weight was achieved. The hull of the rice was removed prior to milling to a fine powder. Additionally, rice samples were cooked in the traditional way to assess the impact of cooking on Hg concentrations. $2 \mathrm{~g}$ of rice samples were digested using nitric and sulphuric acids (Adelojou et al., 1994). Organically bound mercury was released by oxidation with $6 \%$ potassium permanganate solution and mercury was determined by flameless atomic absorption spectrophotometer (Hiranuma HG-1) using $\mathrm{SnCl}_{2}$ as a reduction agent $5 \mathrm{~g}$ subsamples were digested in concentrated $\mathrm{HNO}_{3}$ and $\mathrm{HCl}$ at room temperature overnight, heated on a hot plate, filtered, made up to $100 \mathrm{ml}$ and analysed for $\mathrm{Cd}$ and $\mathrm{Pb}$ by AAS using a Shimadzu AA-6800.

Duplicates, blanks, and certified international reference materials, including National Research Centre for Certified Reference Materials (NRCCRM) rice (GBW08508; $0.038 \mu \mathrm{g} \mathrm{Hg} / \mathrm{g}$ ), and National Research Council, TORT-1 (lobster hepatopancreas; $0.2185 \mu \mathrm{g} \mathrm{Hg} / \mathrm{g}$ ) were used for quality control of rice, banana and aquatic biota analysis. The precision and bias of the chemical analysis was less than $10 \%$ with the exception of some $\mathrm{Pb}$ results, which were re-determined to achieve the required precision (Weeks, 2000).

\subsection{Bananas}


Commercial banana plantations between the Naboc and Mamunga Rivers are spray-irrigated with river water. A thin white film of clay-silt was observed on the leaves and trunks of the banana plants at a site adjacent to the Naboc River, close to the confluence with the Agusan River. Other banana plantations were spray irrigated with water pumped from the Agusan River. Nearly ripe bananas were cut from trees growing under protective plastic bags from three areas each under different irrigation regimes. Bananas were taken from plantations in Mamonga (irrigated by the Naboc), and in Babag and Macopa (located 2 km WSW of Babag), both of which were irrigated by waters from the Agusan River. Banana samples were stored at $5^{\circ} \mathrm{C}$ in a fridge and the edible part analysed for $\mathrm{Hg}, \mathrm{Cd}$ and $\mathrm{Pb}$ (see section 2.2).

\subsection{Aquatic biota}

Mussels were collected from the Naboc River and a pond fed by the river, near to the village of Naboc (Figure 1). They were rinsed in clean bottled water; the edible soft tissues were carefully removed from their shells and the gut contents discarded. Tissue samples were frozen in selfsealing plastic bags at -18 to $-20^{\circ} \mathrm{C}$ (see Williams et al., 1999). Mussels are considered ideal as biomonitors of heavy metal contamination on account of their limited mobility, widespread distribution and tendency for biomagnification of ambient heavy metal concentrations. These freshwater mussels also formed part of the human diet in the region.

Fish (Tilapia spp.) were collected by hook and line fishing from the Naboc River between Naboc and Babag villages and also from a tributary of the Agusan River. Muscle tissue was removed from the freshly killed fish using stainless steel dissecting tools and frozen in Sterilin tubes at -18 to $20^{\circ} \mathrm{C}$. Samples were analysed for $\mathrm{Hg}, \mathrm{Cd}$ and $\mathrm{Pb}$ using the methods described in section 2.2.

\section{Results and discussion}

\subsection{Water quality}


Hg in filtered water samples from the Naboc River (Table 1) exceeds the Philippine water quality criteria for both the protection of public health $(2 \mu \mathrm{g} \mathrm{Hg} / \mathrm{L}$ as total mercury; DENR Administrative Order No. 34, 1990) and fisheries (5 $\mu$ g/L; maximum limit for total Hg; UNEP, 2002). Water from the Naboc River is not abstracted for drinking because it is extremely turbid as a result of discharges from the Diwalwal artisanal mine workings and mineral processing plants. Whereas high Hg loads in solution have been reported previously (Appleton et al., 1999) the general decline in the use of amalgamation for gold extraction suggests that the risk from $\mathrm{Hg}$ in solution has declined.

Total Suspended Solids (TSS) in the Naboc River exceed the DENR Class D water quality criteria (100 mg/L) by a factor of 2 to 73, declining to $59 \mathrm{mg} / \mathrm{L}$ in the Agusan River, about $5 \mathrm{~km}$ downstream of the confluence with Naboc River (Table 1). High suspended sediment load in the Naboc River will effectively prevent the survival of most aquatic macrobiota. Cyanide exceeded DENR drinking water quality criteria (50 $\mu \mathrm{g} \mathrm{CN/l)}$ at the Depot site, but decreased to about $35 \mu \mathrm{g} / \mathrm{L}$ in the lower reaches of the Naboc River. Quality criteria for $\mathrm{Hg}$ and CN are not exceeded in water samples from drinking water wells in the Tubo Tubo, Naboc, Mamonga and Babag areas.

Short-term temporal variation was recorded in $\mathrm{Hg}$ and CN concentrations in filtered water samples, as well as Hg in SS and TSS (Appleton, 2000). This short-term temporal variation in the chemistry of filtered water and suspended particulate matter is very characteristic of rivers impacted by artisanal and small-scale gold mining areas and is an important factor to consider when setting up a water quality monitoring system. If the temporal variations related to changes in contaminant fluxes and hydraulic regime that have been recorded during the present survey are a common occurrence, then concentrations higher than those recorded are likely to occur and may pose a significant hazard to aquatic biota.

\subsection{Sediment quality}


Hg in bottom sediment in the Naboc River varies within a relatively restricted range of 13 to 55 $\mathrm{mg} / \mathrm{kg}$ (Table 2) and is still quite high in SS and BS in the Agusan River, approximately $5 \mathrm{~km}$ below the confluence with the Naboc River (20-25 mg/kg; Figure 1). Historical data indicates that Hg declines to $2 \mathrm{mg} / \mathrm{kg}$ at a site approximately $60 \mathrm{~km}$ further downstream (Appleton et al., 1999). These bottom sediments are a long-term source of $\mathrm{Hg}$ contamination and release of Hg into river water may occur as a result of methylation of $\mathrm{Hg}$ in bottom sediment. There is also the risk that $\mathrm{Hg}$ contaminated sediments will be transferred downstream during periods of high hydraulic flow. Hg concentrations in bottom and suspended sediment in the Naboc and Agusan Rivers (Table 2) exceed the Environment Canada Toxic Effects Threshold for the Protection of Aquatic Life (1 mg/kg; Haines et al., 1994) by factors of up to 55 and 166, respectively. Significant Spearman correlation coefficients were recorded between (1) $\mathrm{pH}, \mathrm{Na}, \mathrm{Hg}, \mathrm{CN}$ and sulphate in filtered water; (2) TSS and (3) Hg and Pb in BS (Figure 3). This reflects the multicomponent contamination derived from the Diwalwal mining settlement, comprising Hg from amalgamation, $\mathrm{Na}$ and high $\mathrm{pH}$ from cyanidation, and $\mathrm{Pb}$ from mineralization.

\subsection{Soil quality}

Rice paddy fields in the Lower and Upper Naboc Communal Irrigation Systems have been irrigated four times a year over the last decade using Hg-contaminated water from the Naboc River. It is reported that 5 to $15 \mathrm{~cm}$ of silt has been deposited in rice paddy fields during the 1990's and that in some areas 2 to $5 \mathrm{~cm}$ of silt is ploughed into the top $10-20 \mathrm{~cm}$ of the soil profile every year. Consequently Hg contaminated silt containing 29-89 mg/kg Hg (Table 3) will be thoroughly mixed into the rice root zone. Hg in rice paddy field soils range between 0.05 to $96 \mathrm{mg} / \mathrm{kg}$ (average 24 $\mathrm{mg} / \mathrm{kg}$; median $12 \mathrm{mg} / \mathrm{kg}$ ). There is, as would be expected, lateral variation in the $\mathrm{Hg}$ concentration away from where silt laden irrigation water enters a field. For example, Hg declines from $66 \mathrm{mg} / \mathrm{kg}$ where irrigation water enters one paddy the field to $4 \mathrm{mg} / \mathrm{kg}$ in the centre of the field, a distance of about 250 metres. $\mathrm{Cu}$ and $\mathrm{Zn}$ exhibit no vertical variation with depth in the soil profile whereas $\mathrm{Pb}$ and Hg decrease by a factor of 2 to 4 (Table 4). 
Hg in the majority of the rice paddy soils exceeded (1) the maximum permissible concentration of Hg in agricultural soil in the UK (1 mg/kg); (2) the Canadian Soil Quality Guideline for agricultural soils (6.6 mg/kg); (3) the UK soil guideline value for inorganic Hg for allotments (8 mg/kg; Environment Agency, 2002); (4) the proposed Dutch Intervention value (SRC - "serious risk concentration”) for inorganic Hg (36 mg/kg; RIVM, 2001); (5) the USEPA soil ingestion Soil Screening Level (SSL) for inorganic Hg (23 mg/kg); and the USEPA SSL for inhalation of volatiles (10 mg/kg; USEPA, 1996). However Hg in the Naboc paddy soils does not exceed either the Dutch proposed human health SRC of $210 \mathrm{mg} / \mathrm{kg}$ or the USEPA generic SSL for plant uptake (270 mg/kg), which implies that the plant uptake pathway is not regarded as a major contributor to exposure compared with soil ingestion (USEPA, 1996). Limit values for $\mathrm{Cd}, \mathrm{Cu}, \mathrm{Pb}$ and $\mathrm{Zn}$ in agricultural soils adopted by the UK are not exceeded in any of the soil samples (Table 3), neither are the Dutch SRCs for human health or the USEPA SSLs for soil uptake (USEPA, 1996) for Cd (24-28 mg/kg) and $\mathrm{Pb}(400-622 \mathrm{mg} / \mathrm{kg})$.

Much lower Hg concentrations within the range expected for uncontaminated soils, characterise soils on which corn and bananas are cultivated, largely because these are not irrigated with Hgcontaminated water from the Naboc River. With the exception of one sample $(0.98 \mathrm{mg} / \mathrm{kg} \mathrm{Hg})$, which was taken from a corn field that appeared to have been used previously for rice cultivation, all corn soils have Hg concentrations below $0.5 \mathrm{mg} / \mathrm{kg}$.

The close correlation between $\mathrm{Hg}$ and $\mathrm{Pb}$ in the rice paddy soils mirrors a similar correlation in bottom sediments (Figure 3). $\mathrm{pH}$ measured in a selection of soils revealed a range of 5.3 to 7.2 but no significant correlations could be detected between $\mathrm{pH}, \mathrm{Hg}$, $\mathrm{Cd}$, or $\mathrm{Pb}$.

\subsection{Rice}

Concentrations of $\mathrm{Hg}$ in rice ranged from $0.008-0.050 \mu \mathrm{g} \mathrm{Hg} / \mathrm{g}$ (wet weight) and between 0.009 $0.058 \mu \mathrm{g} / \mathrm{g}$ dry weight (Table 5). Both cooking the rice by boiling and polishing reduced the level of total inorganic mercury (Table 5). Hg in rice commonly consumed in Saudi Arabia averages $0.0032 \mu \mathrm{g} / \mathrm{g}$ (range < DL - $0.0436 \mu \mathrm{g} / \mathrm{g}$; Al-Saleh \& Shinwari, 2001), whereas a value of $0.0052 \mu \mathrm{g} / \mathrm{g}$ was reported for commercial rice from Italy (Horvat et al., 2003) and 0.005 to 0.034 
$\mu \mathrm{g} / \mathrm{g}$ in wild rice from northern Wisconsin (Bennett et al., 2000). Rice from the mercury-polluted Niigata area of Japan averages $0.003 \mu \mathrm{g} / \mathrm{g}$ (Nakagawa and Yumita, 1998; soil Hg $0.155 \mu \mathrm{g} / \mathrm{g}$ ) and rice cultivated close to a chlor alkali industrial plant in Ganjam, India (Lenka et al., 1992) contained $0.008 \mu \mathrm{g} / \mathrm{g}$. Much higher concentrations ranging up to $0.57 \mu \mathrm{g} / \mathrm{g}$ were recorded from the mercury polluted areas of Wansham and Quingzhen in Guizhou province of China (Horvat et al., 2003).

No significant correlation could be detected between $\mathrm{Hg}$ in rice and soil samples collected from the same general area as where the rice was grown (Figure 4). However, it is difficult to make direct comparison between Hg concentrations in composite soil samples, comprising sub-samples collected from sites about 10-20 m apart and wherever practicable, from two to three adjacent paddy fields, with Hg concentrations in rice grain samples that represent much larger areas. Unfortunately it was not possible to collect soil and rice samples from exactly the same sites because the rice had been harvested shortly before the field programme was carried out.

The relationship between $\mathrm{Hg}$ in soil and un-cooked rice from the Naboc area is compared with data from the Wansham and Quingzhen areas (Horvat et al., 2003) in Figure 5. This illustrates the much higher concentrations of $\mathrm{Hg}$ in rice from the mercury mining area of Wansham whereas rice samples from the vicinity of the chemical plant at Quingzhen, where mercury is used as a catalyst for the production of acetic acid, are similar to Hg levels in the Naboc rice. There appeared to be no correlation between Hg in rice and soil in either area in China (Horvat et al., 2003).

Cd in Naboc rice ranges from 0.057 to $1.025 \mu \mathrm{g} / \mathrm{g}$ with a mean of $0.29 \mu \mathrm{g} / \mathrm{g}$ whilst $\mathrm{Pb}$ ranges from $<0.01$ to $0.430 \mu \mathrm{g} / \mathrm{g}$ with a mean of $0.0479 \mu \mathrm{g} / \mathrm{g}$ (Table 5). In Korea, rice grain grown on soils developed from cadmium-rich uraniferous black shales ranged between 0.1 to $3.5 \mu \mathrm{g} \mathrm{Cd} / \mathrm{g}$ (dry weight) with an average concentration of $0.6 \mu \mathrm{g} / \mathrm{g}$ (Kim \& Thornton, 1988). In the YuguKwangcheon Au-Ag Province of Korea, average concentrations of $\mathrm{Cd}$ and $\mathrm{Pb}$ in the most contaminated paddy soils range up to $8.2 \mu \mathrm{g} / \mathrm{g} \mathrm{Cd}$ and $192 \mu \mathrm{g} / \mathrm{g} \mathrm{Pb}$, whereas corresponding $\mathrm{Pb}$ 
concentrations in rice grain and sesame from these soils ranged between $0.4 \mu \mathrm{g} / \mathrm{g}$ and $6.8 \mu \mathrm{g} / \mathrm{g}$ (Kim et al., 1998). Watanabe et al. (1989) reported geometric mean contents of $\mathrm{Cd}$ and $\mathrm{Pb}$ in Philippine rice of $0.020 \mu \mathrm{g} \mathrm{Cd} / \mathrm{g}$ and $0.016 \mu \mathrm{g} \mathrm{Pb} / \mathrm{g}$ (dry weight) respectively compared with world geometric means of $0.02 \mu \mathrm{g} \mathrm{Cd} / \mathrm{g}$ (dry wt.) and $0.016 \mu \mathrm{g} / \mathrm{g} \mathrm{Pb}$ (Watanabe et al., 1996). Zhang et al. (1996) found that $\mathrm{Pb}$ in Philippines rice grain averaged $0.0376 \mu \mathrm{g} \mathrm{Pb} / \mathrm{g}$. Cadmium and lead in 27 rice grain samples commonly consumed in Saudi Arabia have mean concentrations and ranges of 0.02 (range $<$ DL-0.18) $\mu \mathrm{g} / \mathrm{g}$ and 0.135 (range 0.02-1.53 $\mu \mathrm{g} / \mathrm{g}$ ), respectively (Al-Saleh and Shinwari, 2001).

Rice is generally grown under both oxidising and reducing soil conditions and these conditions will influence the metal uptake by plants. Many investigations have demonstrated that the availability of metals decreased under submerged conditions due to processes of precipitation with hydrides, carbonates and sulphide and iron compounds. Factors influencing metal uptake by rice include soil $\mathrm{pH}$, redox potential, organic matter content, phosphorus content, temperature and time and additionally the cultivar of rice grown (Jung \& Thornton, 1997; McLaughlin et al., 1999). One of the most important factors affecting metal bioavailability is soil $\mathrm{pH}$. A relatively low metal uptake by rice is found under reducing conditions due to increasing soil pH. Jung \& Thornton (1997) showed that metal concentrations in rice plant stalks growing under reducing conditions were lower than those growing under oxidising conditions. Other studies have shown that an increase in soil organic matter content increased the exchangeable Fe and Mn in soils under flooded conditions and thus decreases the availability of metals to plants.

It is also possible that HgS may form in the anoxic layers of rice paddy soils, thereby making the Hg relatively unavailable to plants. However, this is only likely to occur in relatively high sulphur conditions. Equally, adsorption of Hg onto secondary Fe hydroxides when the paddy soil dries out and becomes oxidised will also reduce bioavailability, as will adsorption of Hg onto organic matter in the paddy soils. The availability of metals typically decreases under submerged conditions due to soil metal precipitation, metal sorption and a range of other factors. Lee et al. (1996) reported an increase of soil $\mathrm{pH}$ with increases in the duration of the flooding period for acidic soils, and this 
results in greater $\mathrm{Cd}$ availability reflecting the dynamic change in the chemical forms of $\mathrm{Cd}$ in soils under various flooded conditions. Soil Hg generally has a low availability and plant roots act as a barrier to Hg uptake. In addition, demethylation of $\mathrm{Hg}$ in the upper 10-15 cm of the soil profile may reduce Hg availability. These factors may together explain why relatively little Hg appears to be taken up by the rice plants in the Naboc area. This is fortunate because significant brain damage in animals (rats) is associated with the consumption of $\mathrm{Hg}$ polluted rice (average $0.14 \mathrm{mg} / \mathrm{kg}$ ) from Guizhou province, China (Wang et al. 2004).

The uptake of $\mathrm{Hg}$ is generally much less than for $\mathrm{Cd}$ or $\mathrm{Zn}$, which would explain the relatively high soil/rice grain rations for $\mathrm{Hg}$ compared with Cd (Tables 3 and 5). Watanabe et al. (1996) reported high Cd contents in rice harvested from paddy fields with elevated soil Cd, whereas Cd in Naboc rice is high in relation to the level of Cd in paddy soils ( $<1 \mathrm{mg} / \mathrm{kg}$; Table3). Absorption of Cd may be influenced by flooding the paddy fields, which controls the redox potential of the soil, and hence the uptake of Cd by rice plants.

\subsection{Banana}

$\mathrm{Hg}, \mathrm{Cd}$ and $\mathrm{Pb}$ in banana (Table 6) are low and within appropriate food safety standards for such items. The bananas were commercially grown for export and local consumption is very restricted. The low concentrations are compatible with concentrations in the soils (Table 3).

\subsection{Fish and mussels}

Hg in Tilapia spp. from the Naboc River $(0.277 \mu \mathrm{g} / \mathrm{g})$ is twice as high as in fish from the Agusan River (0.125 $\mu \mathrm{g} / \mathrm{g}$; Table 7), reflecting differences in water, suspended and bottom sediment chemistry in these two rivers (Tables 1 \& 2). Total Hg in fish muscle tissue does not exceed the maximum recommended limit commonly allowed for fish in most countries $(0.5 \mathrm{mg} \mathrm{Hg} / \mathrm{kg}$ wet weight; UNEP, 2002). Hg in the soft edible tissues of $64 \%$ of the mussel samples exceeds the 0.5 
mg Hg/kg wet weight allowed for fisheries products in the European Community although only $18 \%$ of the mussel samples exceed the maximum allowable/recommended level for shellfish in the USA (1 mg methyl Hg/kg; UNEP, 2002). Hg in fish from the Naboc River is much higher than in marine biota (0.004-0.063 $\mu \mathrm{g} / \mathrm{g})$ in the artisanal gold mining impacted area of Libay (Zamboanga del Norte, Mindanao) where sediment Hg concentrations are much lower (0.035 $\mu \mathrm{g} / \mathrm{g}$ ) ( Maramba et al., 2004). Low concentrations of THg in freshwater fish $(0.012 \mu \mathrm{g} / \mathrm{g})$ and clams $(0.18 \mu \mathrm{g} / \mathrm{g})$ (Ramirez et al. 2004) and $0.01 \mu \mathrm{g} / \mathrm{g}$ in Tilapia (Akagi et al., 2000) have been reported also from the Tagum artisanal gold processing area, Mindanao.

\subsection{Metal intake related to rice, fish, and mussel consumption}

The dietary intake of rice by the local residents in the Naboc area is estimated to be $300 \mathrm{~g}$ (airdried) per person per day. The average Hg concentration in rice grain grown in the study area was $0.0149 \mu \mathrm{g} / \mathrm{g}$ (dry wt.), so the amount of mercury entering the body, assuming that locally grown rice is washed and cooked, is $4.47 \mu \mathrm{g} \mathrm{Hg} / \mathrm{day}$. (0.03 mg/week). This value is much lower than the Provisional Tolerable Weekly Intake (PTWI) of $0.3 \mathrm{mg}$ for mercury in the diet set by the WHO and the FAO, of which the maximum intake of MeHg should be no more than $1.6 \mu \mathrm{g} / \mathrm{kg}$ bw (FAO/WHO, 2003). If 50\% of the Hg in Naboc rice were MeHg (see Horvat et al., 2003), then the total weekly MeHg burden from rice would be $15 \mu \mathrm{g}$ MeHg equivalent to only $0.25 \mu \mathrm{g} / \mathrm{kg}$ bw for an adult (bw $60 \mathrm{~kg}$ ). Average total $\mathrm{Hg}$ intake for consumers of Naboc rice is also lower than the Japanese safe guideline limit (0.036 mg/day for an adult weighing 50 kg; Nakagawa \& Yumita, 1998) as well as the Provisional Tolerable Daily Intake (PTDI) for adults ( $0.47 \mu \mathrm{g} / \mathrm{kg}$ bw/day) and for pregnant women and children $(0.2 \mu \mathrm{g} / \mathrm{kg}$ bw/day $)$ in Canada. However, individuals consuming polished and cooked Naboc rice at the upper limit of the Hg concentration range (0.037 $\mu \mathrm{g} / \mathrm{g})$ would have a daily intake of $0.185 \mu \mathrm{g} / \mathrm{kg}$ bw/day, which is almost equal to the Canadian PTDI for children and pregnant women.

The average Cd concentration in rice grain grown in the Naboc area was $0.2907 \mu \mathrm{g} \mathrm{Cd} \mathrm{g}^{-1}$ (wet wt.) so the average daily intake of Cd from consuming 300g of rice is $87.2 \mu \mathrm{g} \mathrm{Cd}$, or $610 \mu \mathrm{g}$ per week. 
This exceeds the Provisional Tolerable Weekly Intake (PTWI) of $420 \mu \mathrm{g}$ Cd recommended by the Joint FAO/WHO Expert Committee on Food Additives (JECFA).

The average $\mathrm{Pb}$ concentration in rice grain grown in the Naboc area is $0.0479 \mu \mathrm{g} / \mathrm{g}$ (wet wt.) so the average daily intake of $\mathrm{Pb}$ from consuming $300 \mathrm{~g}$ of rice is $14.3 \mu \mathrm{g} \mathrm{Pb}$, or $100 \mu \mathrm{g}$ per week. This is only 6.8\% of the Provisional Tolerable Weekly Intake (PTWI) of $1470 \mu \mathrm{g}$ Pb recommended by the Joint FAO/WHO Expert Committee on Food Additives (JECFA).

Fish and fish products are the dominant sources of methyl mercury in the diet and levels greater than $1200 \mu \mathrm{g} / \mathrm{kg}$ have been found in edible marine species such as tuna and swordfish. Similar levels have also been recorded in fish from polluted freshwaters. Consumption of $250 \mathrm{~g}$ of fish from the Naboc River four times a week would result in an intake of $277 \mu \mathrm{g} \mathrm{Hg/week} \mathrm{(Table} \mathrm{7).} \mathrm{This}$ value is close to the Provisional Tolerable Weekly Intake (PTWI) of $300 \mu \mathrm{g}$ for total mercury in the diet recommended by JECFA. If $80 \%$ of the total $\mathrm{Hg}$ in the Naboc fish is MeHg, then the weekly intake is approximately $220 \mu \mathrm{g} \mathrm{MeHg}$ (3.33 $\mu \mathrm{g} / \mathrm{kg} \mathrm{bw}$ ), which is double the JECFA PTWI of $1.6 \mu \mathrm{g} / \mathrm{kg}$ bw (FAO/WHO, 2003). Consumption of $100 \mathrm{~g}$ of the edible portions of freshwater mussels from the Naboc River and adjacent ponds (average 0.59 $\mu \mathrm{g} \mathrm{Hg/g;} \mathrm{Table} \mathrm{7)} \mathrm{each} \mathrm{week}$ would result in an additional MeHg burden of about $50 \mu \mathrm{g}$ MeHg/week.

\section{Conclusions}

Hg in the majority of the rice paddy soils exceeded the UK and Canadian soil quality thresholds for agricultural soils as well as the proposed Dutch Intervention value and the USEPA soil ingestion Soil Screening Level (SSL) for inorganic Hg, although concentrations are less than the Dutch proposed human health value and the USEPA generic SSL for plant uptake. Limit values for Cd, $\mathrm{Cu}, \mathrm{Pb}$ and $\mathrm{Zn}$ in agricultural soils adopted by the UK are not exceeded in any of the soil samples. Much lower Hg concentrations within the range expected for uncontaminated soils, characterise 
soils on which corn and bananas are cultivated, largely because these are not irrigated with Hgcontaminated water from the Naboc River.

The estimated total weekly MeHg intake for a person living in the Naboc-Babag area related to the weekly consumption of $2.1 \mathrm{~kg}$ of locally grown rice (15 $\mu \mathrm{g} \mathrm{MeHg}), 1 \mathrm{~kg}$ of fish (220 $\mu \mathrm{g} \mathrm{MeHg})$ and 100g of mussels (50 $\mu \mathrm{g}$ MeHg), both from the Naboc River, would total $285 \mu \mathrm{g} \mathrm{MeHg}$ (equivalent to $4.75 \mu \mathrm{g} \mathrm{MeHg} / \mathrm{kg}$ bw for a $60 \mathrm{~kg}$ adult) which is almost 3 times the JECFA PTWI of $1.6 \mu \mathrm{g} / \mathrm{kg}$ bw. This will significantly contribute to the population mercury exposure and might explain why $38 \%$ of the local inhabitants were classified as Hg intoxicated during a mercury toxicity assessment (Drasch et al., 2001). Some local people are reported to eat locally caught fish up to three times a day (Drasch et al., 2001), which would substantially increase their exposure to methyl mercury. Not consuming local fish would produce the greatest reduction in exposure to methyl mercury. Inadvertent ingestion of soil containing $24 \mathrm{mg} \mathrm{Hg} / \mathrm{kg}$ at a rate of $20 \mathrm{mg} /$ day (WHO, 2001) or 50mg/day (Campbell, 2003) would give an additional estimated weekly intake of between 3 and $8 \mu$ g THg. The importance of dermal absorption of inorganic mercury and methyl mercury from paddy soil has not been considered but may be an additional exposure route for farmers and their families in the Naboc area. The same applies to the occasional deliberate consumption of soil (pica) or the persistent and purposeful consumption of soil (geophagia), although geophagia is not known to be practised in the Naboc area. A more comprehensive assessment of all Hg exposure routes that includes a systematic dietary survey covering the full range of food types is now required, especially as no plans to remediate the mercury contaminated soils of the Naboc Irrigation Systems have yet been reported. We further recommend the development of a set of water quality criteria specific for this site that would serve as a basis for controlling discharges or releases of heavy metals in the water. These recommended human health water quality criteria would not impose legally binding requirements but would serve to protect the health of consumers of non-commercial freshwater fish. In addition it is recommended that no change of land use from rice to other crops, such as corn, should be permitted unless it can be demonstrated that the alternative crops do not absorb Hg to levels that could further enhance the level of human exposure to mercury. 


\section{Postscript}

The government took control of the mining and mineral processing activities at Diwalwal in 2002 following which mineral processing by mini-CIP plants and ball mills was required to follow environmental and safety rules. Miners constructed their own mini mine tailings dam to temporarily store mine wastes instead of dumping them directly into the Naboc River. The government also terminated the operation of three big mineral processors thereby reducing production from 500-700 tons to just 100 tons per day. It is reported that attempts will be made to rehabilitate the Naboc River once the Mabatas tailings dam has been constructed. Recent DENREMB monitoring has shown that these changes have produced a significant improvement in the water quality of the Naboc River with Hg below the permitted level of $0.002 \mu \mathrm{g} / \mathrm{L}$ and cyanide below the water quality criteria for fresh waters of $0.05 \mathrm{mg} / \mathrm{L}$. Siltation in the lower Naboc has declined to a third of previous levels and TSS in the rest of the river system is now within the public water supply quality standard of $50 \mathrm{mg} / \mathrm{L}$.

\section{Acknowledgements}

The co-operation and enthusiastic support of the following MGB staff involved in the field work (Conrado Miranda, Danilo Berches, Alfredo Relampagos, Patrocinio Simbajon, Jr.) and laboratory analysis (Edith Macalalad, Josephine Uyaco, Teresita Balmes, Ophelia Arreza, and Belen Cawad), is acknowledged with thanks. Advice and assistance received from staff of the Mines and Geosciences Bureau (MGB) in Manila and Davao; the Environmental Quality Division, DENR, RXI, Environmental Management and Protected Areas Service (EMPAS), Davao City; the National Irrigation Administration (Region XI), Davao City, Carmen, and Monkayo; and the local authorities of Monkayo is gratefully acknowledged. 


\section{Bibliography}

Adeloju SB, Dhinsdsa, HS, Tandon, RK. Evaluation of some wet decomposition methods for mercury determination in biological and environmental materials by cold vapour atomic absorption spectroscopy. Anal Chim Acta, 1994;285:359-364.

Akagi H, Castillo ES, Cortes-Maramba N, Francisco-Rivera AT, Timbang TD. Health assessment for mercury exposure among schoolchildren residing near a gold processing and refining plant in Apokon, Tagum, Davao del Norte, Philippines. Sci Tot Environ 2000;259:31-43.

Al-Saleh I, Shinwari N. Report on the levels of cadmium, lead, and mercury in imported rice grain samples. Biol Trace Element Res 2001;83(1): 91-96.

Appleton, JD. A study of the extent of mercury and related chemical pollution along the Naboc River, Monkayo, Davao del Norte; Hijo River, Apokon ore processing site; and their neighbouring areas (rice fields and banana plantations) A report for UNIDO Project DP/PHI/98/00511-02, British Geological Survey, 2000.

Appleton JD, Williams TM, Breward N, Apostol A, Miguel J, Miranda, C. Mercury contamination associated with artisanal gold mining on the island of Mindanao, the Philippines. Sci Total Environ 1999;228:95-109.

Bennett JP, Chiriboga E, Coleman J, Waller DM. Heavy metals in wild rice from northern Wisconsin. Sci Total Environ 2000;246(2-3):261-269.

Böse-O’Reilly S, Maydl S, Drasch G, Roider. G. Mercury as a health hazard due to gold mining and mineral processing activities in Mindanao/Philippines. Final report, UNIDO Project DP/PHI/98/005, Institute of Forensic Medicine, Ludwig-Maximilians University, Munich, Germany, 2000.

Campbell LM, Dixon DG, Hecky RE. A review of mercury in Lake Victoria, East Africa: Implications for human and ecosystem health. Journal of Toxicology and Environmental Health, Part B-Critical Reviews 2003; 6(4):325-356. 
DENR (Environmental Management Bureau). DENR Administrative Order No. 34. Revise water usage and classification Water Quality Criteria Amending Section Nos. 68 and 69. Chapter III of the 1978 NPCC Rules and Regulations (corrected version), 1990.

Drasch GS, Böse-O'Reilly S, Beinhoff C, Roider G, Maydl S. The Mt. Diwata study on the Philippines 1999 - assessing mercury intoxication of the population by small scale gold mining. $\underline{\text { Sci }}$ Total Environ 2001;267(1-3):151-168.

Haines ML, Brydges K, MacDonald MJ, Smith SL, MacDonald DD. A review of environmental quality criteria and guidelines for priority substances in the Fraser River Basin. Supporting Documentation. DOE FRAP 1994-31. Environment Canada, Vancouver, 1994.

Horvat M, Nolde N, Fajon V, Jereb V et al. Total mercury, methylmercury and selenium in mercury polluted areas in the province Guizhou, China. Sci Total Environ 2003;304(1-3): 231-256.

FAO/WHO. Summary and conclusions of the sixty-first meeting of the Joint FAO/WHO Expert Committee on Food Additives (JECFA), Rome, 10-19 June 2003; JECFA/61/SC 2003

Jung MC, Thornton I. Environmental contamination and seasonal variation of metals in soils, plants and waters in the paddy fields around a Pb-Zn mine in Korea. Sci Total Environ1997; 198:105-121

Kim KW, Lee HK, Yoo BC. The environmental impact of gold mines in the Yugu-Kwangcheon Au-Ag metallogenic province, Republic of Korea. Environ Technology 1998;19:291-298.

Kim KW, Thornton I. Influence of uraniferous black shales on cadmium, molybdenum and selenium in soils and crops in the Deog-Pyong area of Korea. Environ Geochem Health 1988;15:119-133.

Lee DY, Chiang PH, Houng KH. Determination of bioavailable cadmium in paddy fields by chelating resin membrane embedded in soils. Plant and Soil 1996;181:233-239. 
Lenka M, Panda KK et al. Monitoring and Assessment of Mercury Pollution in the Vicinity of a Chloralkali Plant .4. Bioconcentration of Mercury in Insitu Aquatic and Terrestrial Plants at Ganjam, India." Archives Environ ContamToxicol 1992; 22(2):195-202.

Maramba NPC, Reyes JP, Francisco-Rivera T, Akagi H, Panganiban LC, Sunio R. Health and Environmental Impact of Mercury in a Gold Mining Community in Western Mindanao, Philippines. In Horvat M et al. (Editors) Mercury as a Global Pollutant. Proceedings of 7th International Conference on Mercury as a Global Pollutant, Slovenia, 2004. RMZ - Materials and Geoenvironment, 2004; 51(1):464-468.

McLaughlin MJ, Parker DR, et al. Metals and micronutrients - food safety issues. Field Crops Research 1999; 60(1-2):143-163.

Nakagawa R, Yumita Y. Change and behaviour of residual mercury in paddy soils and rice of Japan. Chemosphere 1998;37:1483-1487.

Ramirez GB, Del Rosario NL, Francisco-Rivera AT, Dando N, Tapucar R, Akagi H. Sources of Ingested mercury: An Urgent Call For a Food Advisory. In Horvat M et al. (Editors) Mercury as a Global Pollutant. Proceedings of 7th International Conference on Mercury as a Global Pollutant, Slovenia, 2004. RMZ - Materials and Geoenvironment, 2004; 51(1):493-497.

RIVM. Technical Evaluation of Intervention Values for Soil/Sediment and Groundwater. RIVM

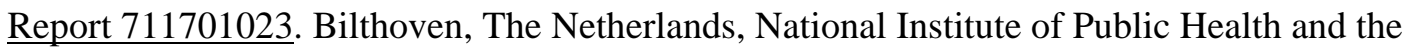
Environment, 2001.

UNEP. Global mercury assessment. Geneva, UNEP Chemicals, 2002.

USEPA. Soil Screening Guidance: Technical Background Document. EPA/540/R95/128, 1996. Wang W, Cheng J, Qu L, Jia J. The Biological Effect of the Rice from Mercury Contaminated Areas in Guizhou Province on the Brain of Rat. In Horvat M et al. (Editors) Mercury as a Global Pollutant. Proceedings of 7th International Conference on Mercury as a Global Pollutant, Slovenia, 2004. RMZ - Materials and Geoenvironment, 2004; 51(1):549-553. 
Watanabe T, Nakatsuka H, Ikeda M. Cadmium and lead contents in rice available in various areas of Asia. Sci Total Environ 1989;80:175-184.

Watanabe T, Shimbo S, Moon CH, Zhang ZW, Ikeda M. Cadmium contents in rice samples from various areas in the world. Sci Total Environ 1996;184:191-196.

Weeks JM. A study of the potential risks to human health from consumption of rice cultivates in paddy fields irrigated by mercury-contaminated mine waste water, Naboc River, Philippines. Report for UNIDO Contract DP/PHI/98/00511-02, 2000.

WHO. Environmental Health Criteria 1: Mercury, Geneva, World Health Organisation, 1976.

WHO. Environmental Health Criteria 86: Mercury - Environmental aspects, Geneva, World Health Organisation, 1989.

WHO. Environmental Health Criteria 101: Methylmercury, Geneva, World Health Organisation, 1990.

WHO. Environmental Health Criteria 118. Inorganic Mercury, Geneva, World Health Organisation, 1991.

WHO. Depleted Uranium: sources, exposure and health effects. Report WHO/SDE/PHE/01.1, Department of the Protection of the Human Environment. WHO: Geneva, 2001.

Williams TM, Weeks JM, Apostol AN, Miranda CR. Assessment of mercury contamination and human exposure associated with coastal disposal of waste from a cinnabar mining operation, Honda Bay, Palawan, Philippines. Environ Geology 1999;39(1):51-60.

Williams, TM, Apostol AN et al. Assessment by hair analysis of mercury exposure among mining impacted communities of Mindanao and Palawan, the Philippines. Environ Geochem Health 2000;22(1):19-31.

Zhang ZW, Moon CS, Watanabe T, Shimbo S, Ikeda M. Lead content of rice collected from various areas in the world. Sci Tot Environ 1996;191:169-175. 
Table 1. Chemistry of filtered water samples from the Naboc River compared with historical data from the Diwalwal artisanal mining area (concentrations in $\mu \mathrm{g} / \mathrm{L}$ )

\begin{tabular}{|c|c|c|c|c|c|c|c|}
\hline & $\begin{array}{r}\text { Depot site, } \\
\text { Naboc } \\
\text { River, } 1 \text { km } \\
\text { below } \\
\text { Diwalwal }\end{array}$ & $\begin{array}{r}\text { Naboc River } \\
\text { (at and below } \\
\text { NIA dam) }{ }^{1}\end{array}$ & $\begin{array}{l}\text { Mamunga R. } \\
\text { \& tributaries }\end{array}$ & $\begin{array}{r}\text { Agusan } \mathrm{R} \\
\text { above Naboc } \\
\mathrm{R}\end{array}$ & $\begin{array}{r}\text { Agusan R } \\
\text { below Naboc } \\
\mathrm{R}\end{array}$ & Well waters & Diwalwal $^{2}$ \\
\hline $\begin{array}{l}\text { No. of } \\
\text { samples }\end{array}$ & 2 & 14 & 3 & 2 & 3 & 9 & Max. \\
\hline $\mathrm{Cu}$ & $100-120$ & $<20$ & $<20$ & $<20$ & $<20$ & $<20$ & 344 \\
\hline $\mathrm{CN}$ & $440-445$ & $20-40$ & $10-30$ & $10-20$ & $8-30$ & $6-46$ & nd \\
\hline $\mathrm{Hg}$ & $7-37$ & $<0.1-42$ & $<0.1$ & $<0.1$ & $<0.1$ & $<0.1$ & 1539 \\
\hline $\begin{array}{l}\mathrm{TSS}^{3} \\
(\mathrm{mg} / \mathrm{L})\end{array}$ & $5055-7357$ & $200-929$ & $57-110$ & $42-57$ & 59-316 & 16 & nd \\
\hline $\mathrm{Zn}$ & $<50$ & $<50$ & $<50$ & $<50$ & $<50$ & $80-1160$ & 81 \\
\hline
\end{tabular}

${ }^{1}$ Drainage samples sites on Naboc River in Figure 1

${ }^{2}$ Appleton et al., 1999; Breward et al, 1996

${ }^{3}$ TSS $=$ Total Suspended Solids

nd = not determined 
Table 2. Chemistry of suspended (SS) and bottom (BS) sediment samples and concentration of Total Suspended Solids (TSS) for the Naboc River area (concentrations in mg/kg, except TSS).

\begin{tabular}{lrrrrr}
\hline & $\begin{array}{r}\text { Depot site, } \\
\text { Naboc River, } \\
1 \text { km below } \\
\text { Diwalwal }\end{array}$ & $\begin{array}{r}\text { Naboc River } \\
\text { (a) } \begin{array}{c}\text { NIA dam) }{ }^{1} \\
\text { Namunga R. }\end{array}\end{array}$ & $\begin{array}{r}\text { Agusan R } \\
\text { \& tributaries }\end{array}$ & $\begin{array}{r}\text { Agusan R } \\
\text { above Naboc R } \\
\text { below Naboc R }\end{array}$ \\
\hline No. of & 2 & 14 & 3 & & \\
samples & & & & & \\
Cd SS & $<1$ & $<1-2$ & $<1-2$ & $2-5$ & $<1-5$ \\
Cd BS & $<1$ & $<1$ & $<1$ & $<1$ & $<1$ \\
Cu SS & 46 & $35-55$ & $53-83$ & $108-126$ & $69-268$ \\
Cu BS & $67-76$ & $39-57$ & $65-74$ & $73-85$ & $61-74$ \\
Hg SS & $28-37$ & $52-166$ & $5-84$ & $<0.04-2$ & $27-124$ \\
Hg BS & $13-17$ & $13-55$ & $2-51$ & 0.1 & $17-33$ \\
Pb SS & $33-38$ & $57-120$ & $<10-65$ & $<10$ & $14-186$ \\
Pb BS & $37-40$ & $20-32$ & $<10-25$ & $<10$ & $17-19$ \\
TSS (mg/L) & $5055-7357$ & $200-929$ & $57-110$ & $42-57$ & $59-316$ \\
Zn SS & $70-82$ & $64-145$ & $135-275$ & $157-254$ & $136-642$ \\
Zn BS & $75-89$ & $49-121$ & $57-112$ & $57-61$ & $66-79$ \\
\hline
\end{tabular}

\footnotetext{
${ }^{1}$ Drainage sample sites on Naboc River - see Figure 1
} 
Table 3. Mean and range of $\mathrm{Cd}, \mathrm{Cu}, \mathrm{Hg}, \mathrm{Pb}$ and $\mathrm{Zn}$ in surface soils from the rice paddy soils of the Lower and Upper Naboc Irrigation Systems and adjoining areas of banana and corn cultivation compared with silt deposited in irrigation canals and soil quality criteria (concentrations in $\mathrm{mg} / \mathrm{kg}$ ).

\begin{tabular}{lrrrrr}
\hline & Rice paddy soil & Banana soil & Corn soil & Irrigation canal silt $^{\text {EC (UK) Limit Values }}{ }^{1}$ \\
\hline No. of samples & 58 & 9 & 9 & 3 & $1-3(3)$ \\
$\mathrm{Cd}$ & $<1$ & $<1$ & $<1$ & $<1$ & $50-140(135)$ \\
$\mathrm{Cu}$ & $63(35-105)$ & $65(49-118)$ & $61(46-84)$ & $56(41-67)$ & $1-1.5(1)$ \\
$\mathrm{Hg}$ & $24.3(0.05-96)$ & $0.12(0.05-0.3)$ & $0.27(0.08-0.99)$ & $82(29-89)$ & $22-38$ \\
$\mathrm{~Pb}$ & $14(<10-56)$ & $<10$ & $<10$ & $67(48-80)$ & $150-300(300)$ \\
$\mathrm{Zn}$ & $72(37-121)$ & $67(45-86)$ & $64(43-82)$ & & \\
\hline
\end{tabular}

\footnotetext{
${ }^{1}$ Limit values for concentrations of heavy metals in soils (EC Directive 86/278/EEC on the protection of the environment, and in particular of the soil, when sewage sludge is used in agriculture. Permitted range (value adopted by the UK in brackets))
} 
Table 4. $\mathrm{Cu}, \mathrm{Pb}$, Zn and $\mathrm{Hg}$ in two rice paddy field soil profiles (concentrations in $\mathrm{mg} / \mathrm{kg}$; see Figure 1 for location of profiles P1 and P2)

\begin{tabular}{llllllll}
\hline $\begin{array}{l}\text { Profil } \\
\mathrm{e}\end{array}$ & $\begin{array}{l}\text { Depth of } \\
\text { sample }\end{array}$ & soil type & $\mathrm{Cu}$ & $\mathrm{Pb}$ & $\mathrm{Zn}$ & $\mathrm{Cd}$ & $\mathrm{Hg}$ \\
\hline $\mathrm{P} 1$ & $2-8 \mathrm{~cm}$ & brown clay silt & 69 & 23 & 87 & $<1$ & 40.0 \\
& $10-20 \mathrm{~cm}$ & grey clay silt & 62 & $<10$ & 84 & $<1$ & 12.4 \\
\hline P2 & $5-10 \mathrm{~cm}$ & grey silt & 57 & 29 & 85 & $<1$ & 49.6 \\
& $15-20 \mathrm{~cm}$ & $\begin{array}{l}\text { mottled brown clay- } \\
\text { silt }\end{array}$ & 57 & 11 & 85 & $<1$ & 12.8 \\
& & & & & & \\
\hline
\end{tabular}


Table 5. Mean concentrations and ranges of $\mathrm{Hg}, \mathrm{Cd}$ and $\mathrm{Pb}$ in rice grains sampled in the vicinity of the communal irrigation area (metal values are $\mu \mathrm{g} / \mathrm{g}$ dry weight, unless otherwise stated).

\begin{tabular}{|c|c|c|}
\hline Rice grain & Mean & Range \\
\hline \multicolumn{3}{|l|}{$\mathrm{Hg}$} \\
\hline Polished + cooked & 0.015 & 0.006-0.037 \\
\hline Polished + not cooked & 0.018 & $0.008-0.050$ \\
\hline Unpolished & 0.020 & $0.001-0.043$ \\
\hline Dry weight & 0.021 & $0.009-0.058$ \\
\hline Wet weight & 0.016 & $0.008-0.050$ \\
\hline Cd (wet wt.) & $0.291(0.020)^{\mathrm{a}}$ & $0.057-1.025$ \\
\hline $\mathrm{Pb}$ (wet wt.) & $0.0479(0.038)^{\mathrm{b}}$ & $0.043-0.430$ \\
\hline
\end{tabular}

${ }^{\mathrm{a}}$ Geometric mean value for the Philippines based on 26 samples from Watanabe et al. (1996)

${ }^{\mathrm{b}}$ Geometric mean value for the Philippines based on 26 samples from Zhang et al. (1996). 
Table 6. Mean concentrations ( $\mu$ g/g wet wt.) of $\mathrm{Cd}$, $\mathrm{Hg}$ and $\mathrm{Pb}$ banana.

\begin{tabular}{lllll} 
Site (Source of irrigation water) & n. & Cd & Hg (range) & $\mathrm{Pb}$ \\
\hline Mamonga (Naboc River) & 5 & 0.27 & $0.016(0.007-0.039)$ & $<0.01$ \\
Makopa (Agusan River) & 5 & 0.17 & $0.011(0.008-0.066)$ & $<0.01$ \\
Babag (Anaan River) & 5 & 0.13 & $0.016(0.008-0.016)$ & 0.03 \\
\hline
\end{tabular}


Table 7. Mean concentrations ( $\mu \mathrm{g} / \mathrm{g}$ wet wt.) of $\mathrm{Cd}, \mathrm{Hg}$ and $\mathrm{Pb}$ in fish (Tilapia spp.) and mussels collected from the Naboc and Agusan Rivers.

\begin{tabular}{|c|c|c|c|c|}
\hline Species Sample Site & No. & $\mathrm{Cd}$ & Hg (range) & $\mathrm{Pb}$ \\
\hline \multicolumn{5}{|l|}{ Fish (Tilapia spp.) } \\
\hline Agusan tributary & 7 & 0.13 & $0.125(0.109-0.156)$ & 0.16 \\
\hline Naboc River & 3 & 0.13 & $0.277(0.146-0.494)$ & $<0.01$ \\
\hline \multicolumn{5}{|l|}{ Mussels (Taiwan clam) } \\
\hline Naboc River & 8 & 0.12 & $0.315(0.233-0.554)$ & 0.22 \\
\hline Pond adjacent to Naboc River & 14 & 0.16 & $0.869(0.296-1.208)$ & 0.24 \\
\hline
\end{tabular}




\section{Figure captions}

Figure 1. Hg in drainage (bottom sediment and canal silt) and soil in the Naboc River and adjoining areas (see Figure 1 in Appleton et al., 1999 for location of survey area; all soil samples are from rice paddy fields except those marked $\mathbf{b}$ (banana soil) and $\mathbf{C}$ (corn soil); $\mathbf{P} \mathbf{1}$ and $\mathbf{P} \mathbf{2}$ are soil profile locations).

Figure 2. Comparison of analytical results for water $(\mu \mathrm{g} / \mathrm{L})$ and sediment $(\mathrm{mg} / \mathrm{kg})$ samples analysed at the MGB and BGS laboratories.

Figure 3. Correlation between $\mathrm{Hg}$ and $\mathrm{Pb}$ in soil and bottom sediment, Naboc area.

Figure 4. Relationship between Hg in soil and rice, Naboc River area

Figure 5. Concentration of $\mathrm{Hg}$ in soil and rice from the Naboc area compared with the Quingzhen and Wanshan areas in China (Horvat et al., 2003) 


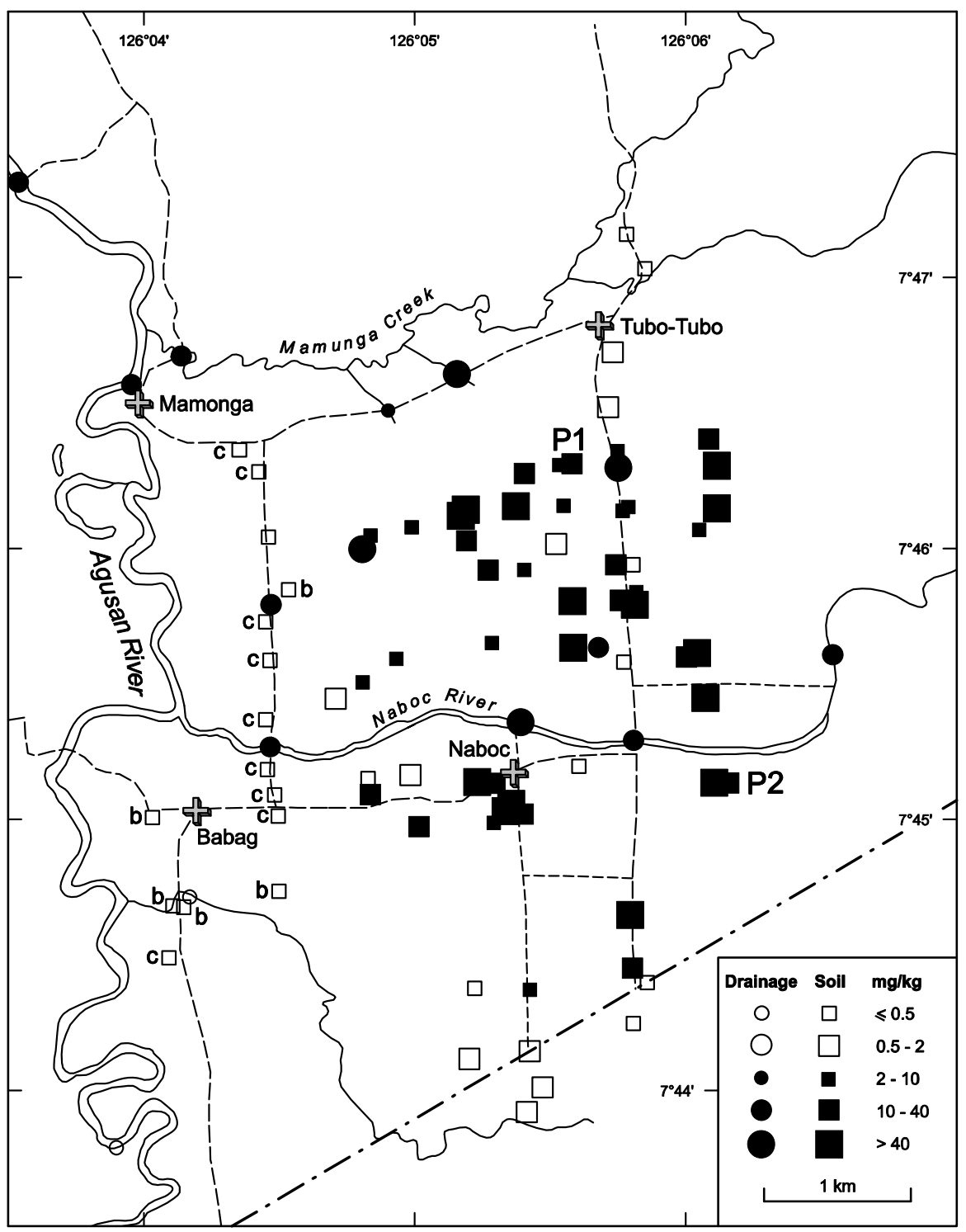

Appleton Naboc Figure 1 


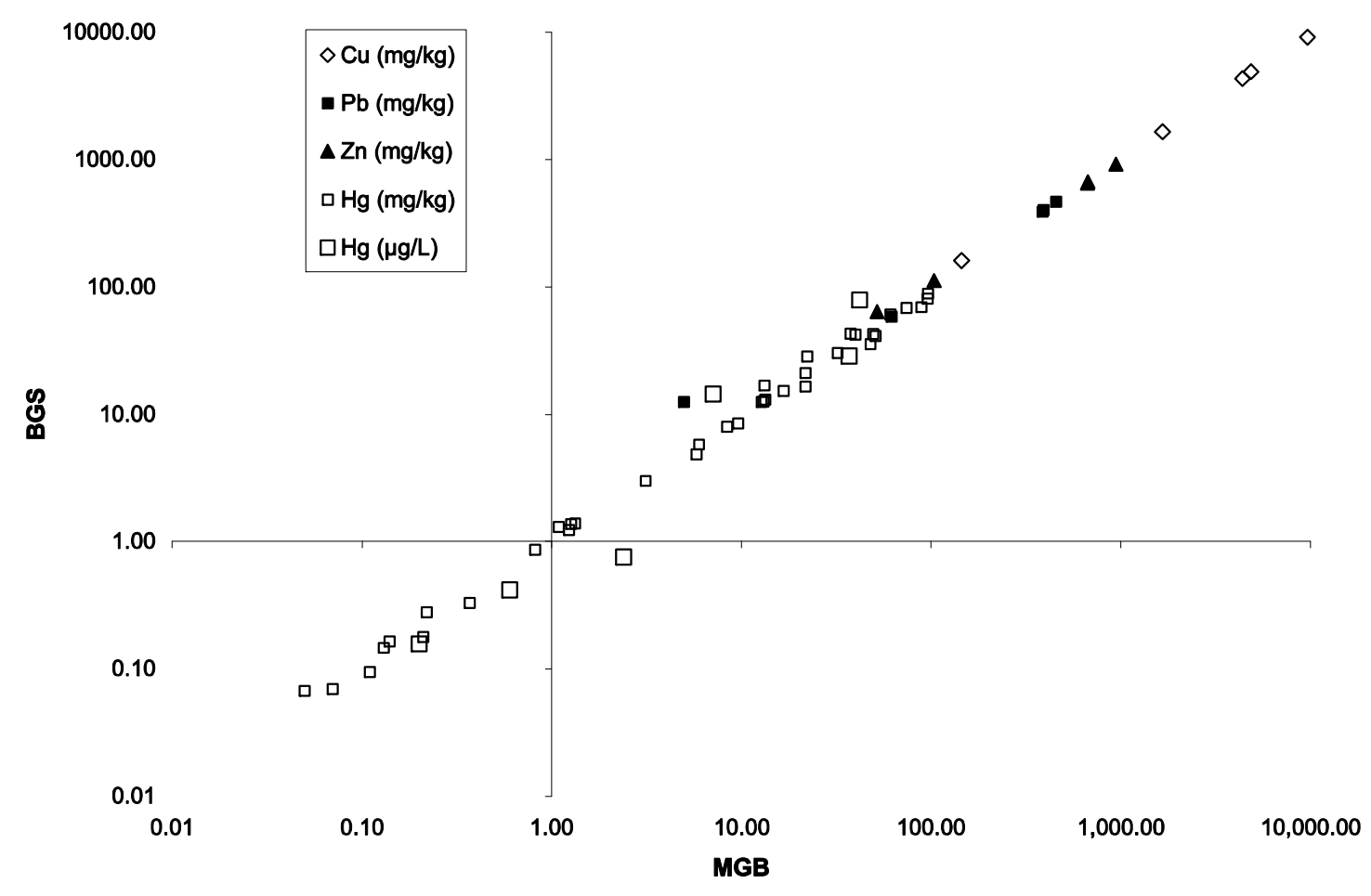

Appleton Naboc Figure 2 


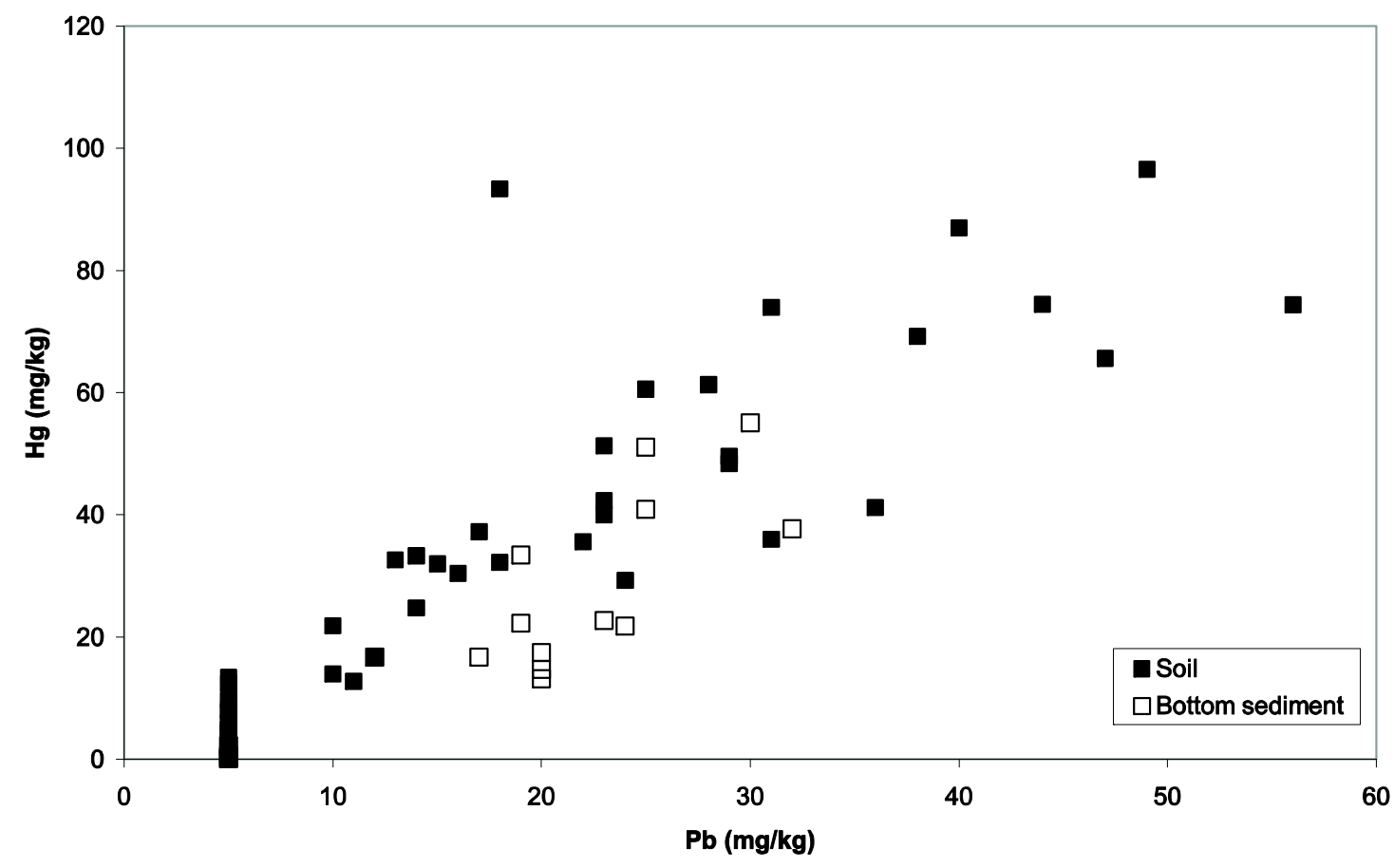

Appleton Naboc Figure 3 


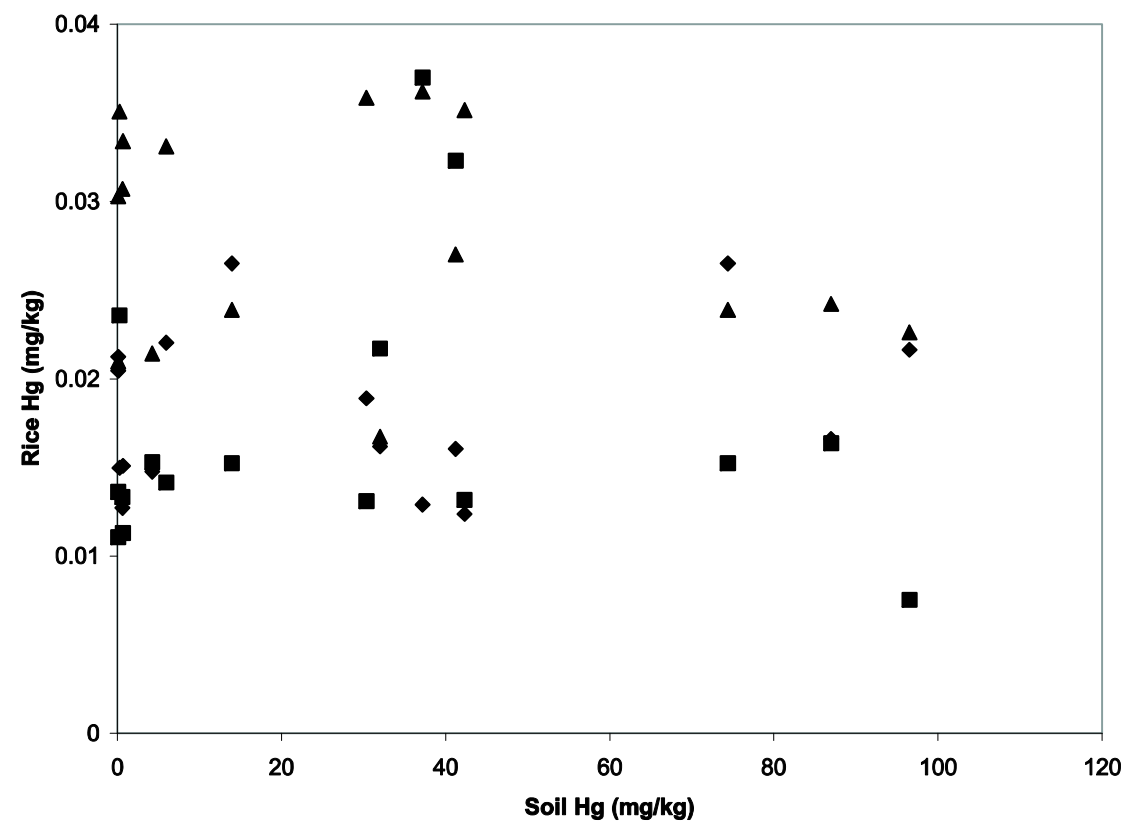

- Un-cooked rice $\mathrm{Hg}(\mathrm{mg} / \mathrm{kg})$

- Cooked rice $\mathrm{Hg}(\mathrm{mg} / \mathrm{kg})$

$\Delta$ Rice hull $\mathrm{Hg}(\mathrm{mg} / \mathrm{kg})$

Appleton Naboc Figure 4 


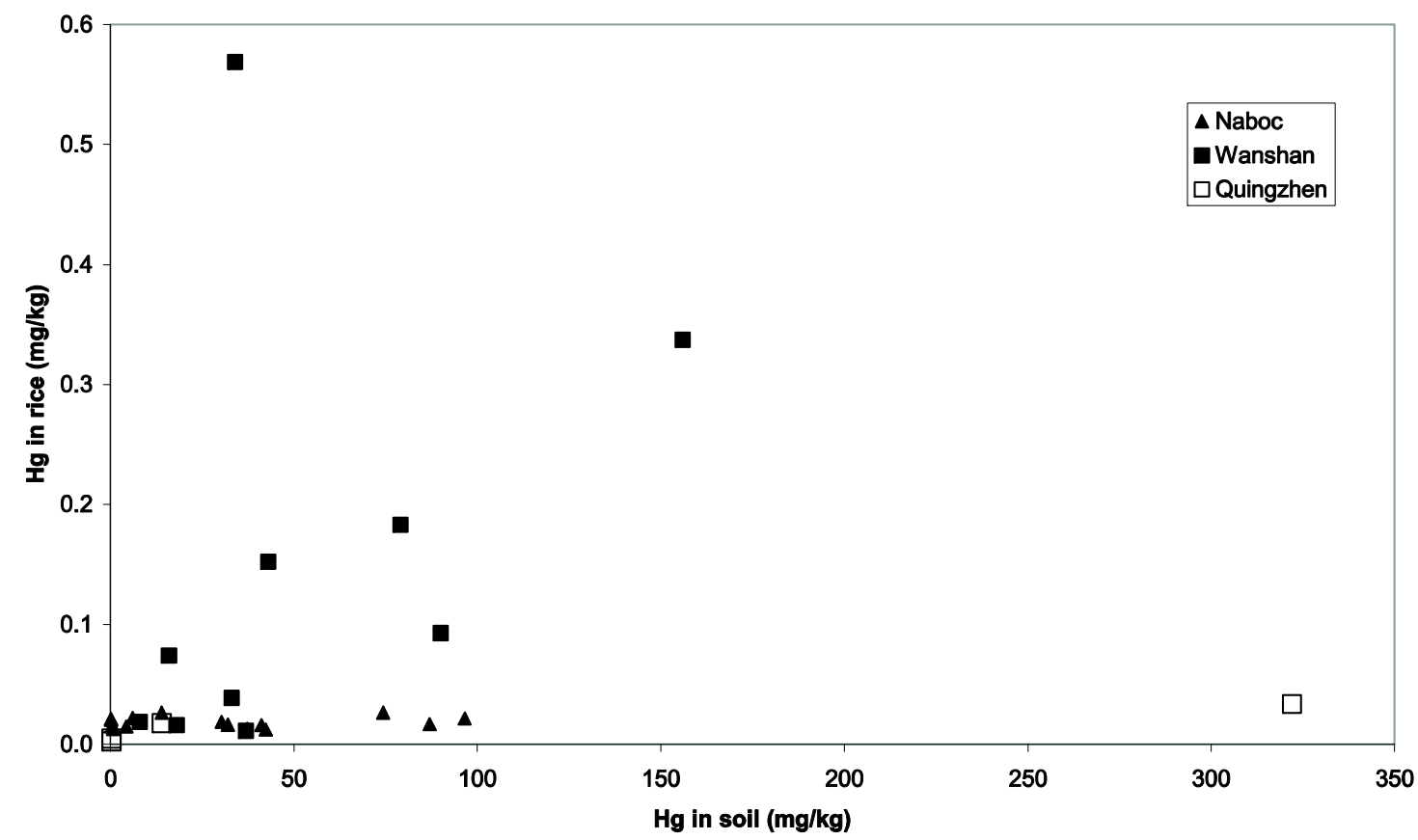

Appleton Naboc Figure 5 